\title{
Mercado Simbólico: um modelo de comunicação para políticas públicas
}
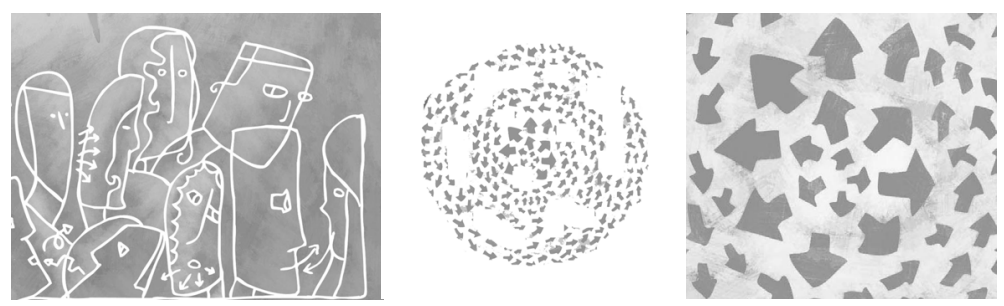

Inesita Soares de Araújo ${ }^{1}$

ARAújO, I. S. The symbolic market: a communication model for public policies, Interface - Comunic., Saúde, Educ., v.8, n.14, p.165-77, set.2003-fev.2004.

The purpose of this paper is to put forth a model for the analysis and strategic planning of the communication of public policies, given that the current models fail to adequately fulfill communication requirements in the processes of social intervention, frustrating the high investments and expectations that they give rise to. The "Symbolic Market Model", in network form, both decentralized and multipolar, is comprised of (i) a theoretical formulation, (ii) a graphical representation of the main components and the relations between them and (iii) an analysis and strategic planning matrix of communicative relations. The graphic representation takes into account: the network of social senses, the interlocutors and their contexts, and the "place of dialogue". The matrix includes sources, fields, instances, discursive communities and a typology of mediation factors.

KEY WORDS: Communication and public policies; communication models; strategic planning.

O trabalho tem como objetivo propor um modelo para análise e planejamento estratégico da comunicação nas políticas públicas, considerando que os modelos correntes não dão conta adequadamente da prática comunicativa nos processos de intervenção social, frustrando os altos investimentos e expectativas que despertam. O "Modelo do Mercado Simbólico", em rede, descentrado e multipolar, é composto por uma formulação teórica, uma representação gráfica dos principais componentes e suas relações e de uma matriz de análise e planejamento estratégico das relações comunicativas. A representação gráfica contempla: a rede de sentidos sociais, os interlocutores e seus contextos e "lugar de interlocução". A matriz inclui fontes, campos, instâncias, comunidades discursivas e uma tipologia de fatores de mediação.

PALAVRAS-CHAVES: Comunicação e políticas públicas; modelos de comunicação; planejamento estratégico.

${ }^{1}$ Pesquisadora do Centro de Informação Científica e Tecnológica e do Departamento de Comunicação e Saúde da Fundação Oswaldo Cruz (CICT/DCS/Fiocruz). <isoares@cict.fiocruz.br> 
Por determinadas contingências históricas, o modelo de comunicação mais adotado no campo das políticas públicas, em geral e especificamente no da saúde coletiva é o da Comunicação \& Desenvolvimento, introduzido no Brasil nos anos 1950, no contexto da luta contra o comunismo internacional. Subsidiário do modelo informacional de Shannon \& Weaver, (apud Araújo, 2000), concebe a comunicação como moldagem de atitudes e comportamentos, que se efetivaria por meio de informação suficiente $e$ adequada. É um modelo bipolar, linear, unidirecional e vertical, não dando conta da complexidade da prática comunicativa e social. Este trabalho objetiva apresentar um outro modelo que, sem abrir mão de conquistas dos anteriores, pretende representar mais adequadamente os processos sociais de formação dos sentidos e a prática comunicativa na intervenção social.

Qualquer produto, uma vez pronto e em circulação, passa a ser visto de forma isolada das condições sociais que o formaram. Com modelos não é diferente e o modelo da Comunicação \& Desenvolvimento oculta hoje suas condições de produção, fortalecendo sua presença. Oculta também o que está fora do modelo, impedindo uma compreensão mais abrangente da realidade. Ao longo da minha experiência de ensino para profissionais da agricultura, saúde e campos correlatos, pude sempre constatar tanto a presença hegemônica desse modelo nas práticas institucionais, como uma insatisfação com seus limites, ainda que disto não se tenha clareza, até mesmo porque estamos falando de uma hegemonia, no pleno sentido do conceito. Atualmente, em alguns espaços a noção de "comunicação" vem sendo substituída pela de "informação", conceito que prejudica a compreensão dos processos sociais implícitos e implicados no conceito de comunicação, quando usado como equivalente deste. "Informação", assim utilizado, é um conceito predador, que engole as dimensões histórica, política e econômica das relações sociais e oculta os interesses em luta. A substituição em nada modifica a natureza $e$ as conseqüências do modelo desenvolvimentista.

Uma dificuldade do modelo desenvolvimentista em dar conta da realidade comunicativa está na sua natureza linear e unidirecional. A comunicação é entendida como um processo de repasse de mensagens de um pólo a outro, cuja maior preocupação, além de utilizar códigos reconhecíveis, é eliminar os chamados ruídos, as interferências que possam prejudicar a decodificação dessas mensagens. Ou seja: eliminar a polifonia social e discursiva e garantir a linearidade do processo. Ao fazer isto, promove a dissolução tecnocrática do político, para usar uma expressão de Barbero (1993). De fato, ao eliminar a polifonia, o modelo não considera as divergências, eliminando aquilo que representa justamente o confronto de interesses. "A tendência é, então, deixar sem sentido as contradições, por considerá-las não como expressões de conflitos, mas como resíduos de ambigüidade" (Barbero, 1993, p.224). Um outro ponto de estrangulamento é a concepção de significado, entendido como algo imanente aos códigos lingüísticos, portanto algo transferível.

O deslocamento ocorrido a partir dos anos 1980, em alguns espaços acadêmicos e institucionais, que inverteu o foco do processo comunicativo, atribuindo ao receptor a responsabilidade pela produção dos sentidos, 
pouco mudou o caráter funcionalista da comunicação (Mattelart, 1999). Desde os anos 1950, a partir da teoria da Comunicação em Duas Etapas, depois com a corrente dos Usos e Gratificações, já havia o reconhecimento da importância do receptor, sem que isto modificasse traços essenciais desses modelos, a bipolaridade e a linearidade do processo comunicativo. Assim, tomam-se dois pólos e são estabelecidas suas relações, apenas invertendo-se o protagonismo da relação. $O$ deslocamento para o receptor repete a limitação dos modelos dominantes: oculta as determinações estruturais, as relações de poder, as contradições. Se o estruturalismo levava a um emissor e um receptor abstrato, o empirismo dos estudos atuais de recepção produz um receptor tão concreto que oculta a sociedade em que vive.

Não obstante, outras possibilidades vão se esboçando: são postas em cena as mediações e negociações, nos diversos âmbitos e entre os diversos atores e fatores que formam a prática comunicativa. Adquirem relevância as noções de consumo (Certeau, 1994; Canclini, 1995), mediações culturais (Barbero, 1993; Orozco, 1997), táticas e estratégias (Certeau, 1994), entre outras. É nesse contexto teórico que minha proposta se inscreve.

Introdução ao modelo do mercado simbólico O modelo que proponho deseja representar a prática comunicativa nos processos de intervenção social que dão concretude às políticas públicas. Para tanto, articulei elementos conceituais já existentes em outros quadros teóricos, acrescentei o conceito de lugar de interlocução e propus uma formulação básica, com uma correspondente representação gráfica. Que formulação é esta?

A comunicação opera ao modo de um mercado, onde os sentidos sociais - bens simbólicos - são produzidos, circulam e são consumidos. As pessoas e comunidades discursivas que participam desse mercado negociam sua mercadoria - seu próprio modo de perceber, classificar e intervir sobre o mundo e a sociedade - em busca de poder simbólico, o poder de constituir a realidade.

Detalhando os termos:

1. Comunicação é o processo de produzir, fazer circular e consumir os

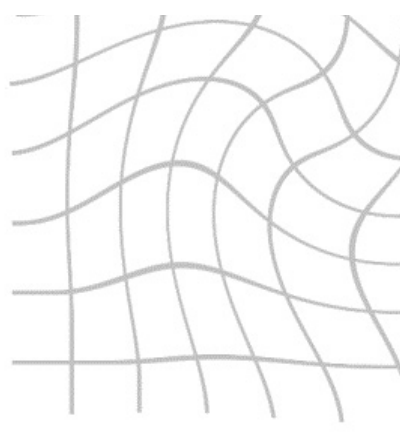
sentidos sociais, que se manifestam por meio de discursos.

2. Esse processo caracteriza um mercado simbólico, no qual o circuito produtivo é mediado por uma permanente negociação.

3. Esse mercado pode ser operado por indivíduos ou por comunidades discursivas, considerados no modelo como interlocutores.

4. Comunidades discursivas são grupos de pessoas, organizados ou não de forma institucional, que produzem e fazem circular discursos, que neles se reconhecem e são por eles reconhecidos.

5. Cada interlocutor ocupa nesse mercado uma posição, que se localiza entre o centro e a periferia discursivos, posição que corresponde ao seu lugar de interlocução e lhe confere poder de barganha no mercado simbólico.

6. Cada interlocutor desenvolve estratégias de trânsito entre as posições, 
visando sempre uma maior aproximação com o Centro. Essas estratégias se apóiam em fatores de mediação, que são os fatores que favorecem ou dificultam o fluxo entre as posições.

7. Os fatores de mediação são de ordem pessoal, grupal, coletiva ou organizacional, material ou simbólica e ocorrem em contextos, cuja articulação determina o lugar de interlocução.

A construção social dos mercados

Apesar do destaque adquirido na contemporaneidade, mercado é uma categoria de análise presente na teoria econômica desde o séc. XVIII e, na sua concepção capitalista, aparece na História desde a revolução industrial. São diferentes, porém, os modos de considerá-lo. Desejo destacar dois deles, o que fundamenta a idéia de "mercado livre" e o que mais se aproxima da concepção do mercado simbólico, que é o da "construção social dos mercados".

O primeiro configura a perspectiva neoclássica, que sustenta que os atores se encontram individualmente para transacionar, em busca do preço melhor e acredita no homem econômico, que independe do jogo social ou político. Acredita também que o único interesse seria a maximização do lucro e que, como qualquer fenômeno, o mercado possuiria leis próprias de funcionamento. Outra crença é que a informação está disponível de modo igual para todos.

Em contraposição, temos a perspectiva institucionalista, que afirma que o mercado está social e culturalmente enraizado; que funciona segundo fatores como confiança, reciprocidade, costume etc.; que, além do preço, há outros elementos que definem as escolhas; que o acesso à informação é assimétrico. Sendo sustentado por um conjunto de instituições (jurídicas, sociais, políticas...), as relações nesse mercado são estruturadas pelos interesses em jogo.

A noção de interesses remete para a de confronto e luta, pois os interesses não são harmônicos. Pelo contrário, vivemos numa sociedade desigual, com distribuição desigual dos recursos de toda ordem. Nesta perspectiva, devemos admitir que uma negociação de desiguais não pode prescindir do caráter de luta. É por isto que podemos operar ao mesmo tempo com uma perspectiva de luta simbólica e com um modelo que privilegia a noção de mercado: o mercado simbólico é um mercado de desiguais e a negociação que nele se processa tem o caráter de luta por posições de poder discursivo. Como toda luta, supõe confrontos e embates, mas também acordos, alianças, sinergias. Mas, quero ainda argumentar a favor da opção por um modelo de mercado, ao enfocar a prática comunicativa.

Quando Bourdieu (1989) escreveu Ce que parler veut dire ("o valor exato do que é dito", numa tradução livre desta expressão popular francesa), estava se contrapondo a uma teoria estruturalista, baseada fortemente na lingüística, que se coloca diante dos fenômenos simbólicos como se estivesse lidando com línguas mortas, estáticas, diante das quais se deve reconstituir o código. É como se o fenômeno social que o texto expressa tivesse sido produzido para ser decifrado pelo cientista. O modelo bourdineano diz 
respeito a uma teoria da ação, em particular ao ato de fala.

A expressão francesa remete para a compreensão de que existe algo mais no ato de falar do que simplesmente a língua. Tal como Bakhtin (1988), Bourdieu (1993) substitui o ponto de vista da língua pelo ponto de vista da fala. E, além de trabalhar com a competência lingüística, comum a todos os lingüistas, ele enfoca a competência para usar corretamente a competência. A essa situação ele chamou de "mercado". E, quem fala de mercado, fala de capital, no caso dele capital simbólico.

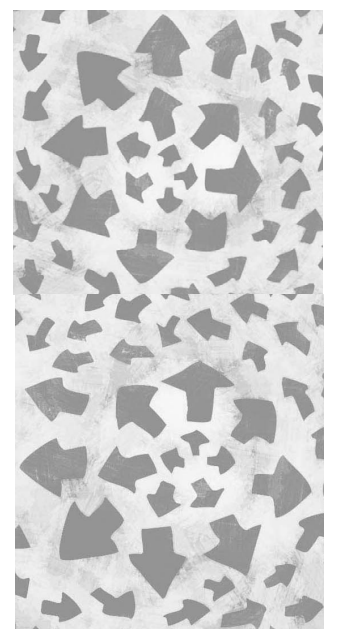

Quando falamos, produzimos um produto que, sob certo aspecto, é um produto como outro qualquer, portanto, destinado a estar sujeito não só à interpretação, mas também à avaliação. (...) A antecipação do preço que o produto vai receber vai intervir no nível da produção. Concretamente, isso significa que, quando produzo um determinado discurso, preocupo-me mais ou menos com o efeito que ele vai produzir naquele a quem o dirijo. A antecipação do preço que meu discurso receberá ajuda a determinar a forma e o conteúdo dele, que será mais ou menos tenso, mais ou menos censurado, às vezes até o ponto de ser anulado - é o silêncio da intimidação. Se meu discurso pode receber um preço, isso ocorre porque quando falo, digo o que digo, mas também digo algo a mais na maneira de dizê-lo. (Araújo, 2000, p.53)

Ele fala então da aceitabilidade, um conceito que determina justamente o que pode ou não ser dito em tal ocasião ou tal lugar. Para ele, este senso de aceitabilidade, que temos em estado prático, exerce coerção sobre o discurso. É aí que entra a questão da "competência" para falar, ou seja, das distinções sociais que se exercem no domínio da fala. As competências concorrem entre si e definem o valor que será atribuído a cada fala. Voltamos então ao tema do mercado simbólico, espaço dessa concorrência, na qual intervêm inúmeros fatores. A competência lingüística se exerce desigualmente, ela é monopolizada por alguns, outros são despossuídos em graus variados. Essas desigualdades manifestam-se nas trocas cotidianas. A competência é, por outro lado, um diferencial social, não só acentua, mas produz as diferenças sociais. Então a língua, para Bourdieu, não é um tesouro comum, mas um artefato histórico, o produto de um trabalho social operado pelos agentes em situação de concorrência.

Em outro lugar, Bourdieu (1989) fala mais deste tema, tratando o espaço comunicativo como um mercado lingüístico, do qual ele destaca algumas propriedades. Uma, a de ser um espaço pré-construído, ou seja, operado por um grupo social determinado, regido por regras determinadas, que estabelecem, entre outras coisas, quem pode falar e o que se pode falar. Outra, ser o lugar da atualização da interseção entre os diferentes campos. Em outras palavras, ele põe em cena as múltiplas negociações que se verificam no mercado simbólico, desde as textuais até as macrocontextuais. E realça a importância daquilo que eu chamo de contexto situacional, como a pertença a campos e o lugar que ali ocupam - o "lugar de interlocução", 
nos termos deste trabalho. As estratégias discursivas dependem das relações de força entre os campos e os trunfos que a pertença a estes campos conferem ao interlocutor.

A partir da noção de comunicação como um mercado simbólico, pode-se definir a prática comunicativa como o ato de ativar o circuito produtivo dos sentidos sociais. Produção e circulação são seu espaço mais evidente. Mas, se considerarmos o processo de semiose infinita, que estabelece que cada receptor/consumidor é também um produtor de novos sentidos, a partir mesmo do ato e dos modos de consumir, então o consumo é espaço essencial da comunicação.

Uma estratégia de comunicação é, então, o modo como se ativa algum fragmento desse circuito e como se participa do mercado simbólico, lugar onde os sentidos sociais são produzidos. Se pensarmos que a prática discursiva está submetida a condições de desigualdade do poder simbólico poder de constituir a realidade - e se pensarmos na noção de intertexto $e$ interdiscursividade presentes na formação dos sentidos sociais, teremos que pensar que é imprescindível perceber como relevante o processo de formação dos sentidos sociais. No fim da linha, estão conceitos como liberdade, democracia, cidadania, política. A perspectiva do mercado simbólico é um modo de compreender como se formam os sentidos sociais, portanto, como se formam as condições de percepção $e$ ação das pessoas sobre o mundo.

Passemos, porém, à visualização dos componentes do modelo.

\section{Representação gráfica do modelo}

\section{Sentidos sociais}

Os sentidos sociais formam uma rede semiótica, dinamizada pela interdiscursividade. O processo de produção - circulação - consumo, que caracteriza o mercado simbólico, é representado no modelo por uma malha de fios, cujo traçado ondulante busca caracterizar a contínua transformação dos sentidos, em seu processo de circulação.

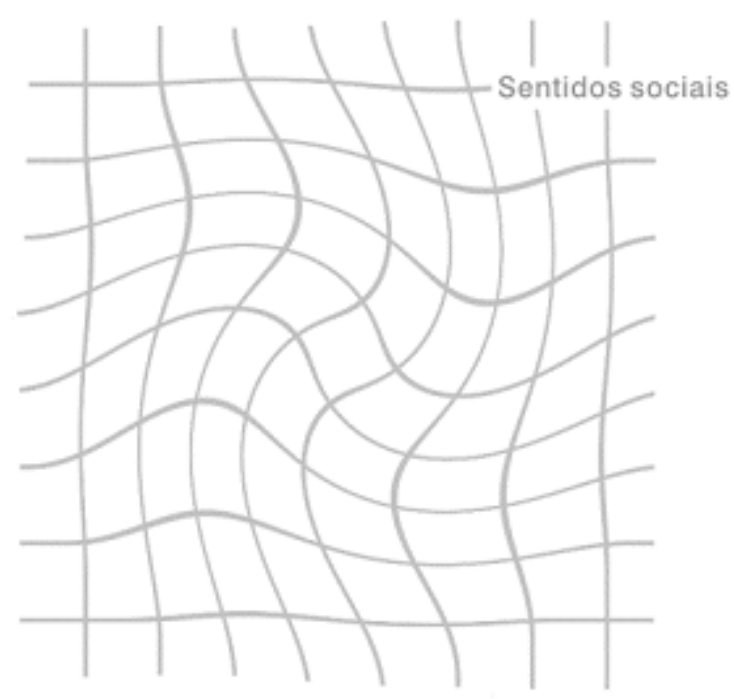




\section{Os interlocutores}

A produção, circulação e consumo dos sentidos sociais é mediada por um processo de negociação, que é operada por pessoas e comunidades discursivas, os "interlocutores". O modo de cada interlocutor participar do mercado simbólico é produto da articulação de vários contextos, sendo que os mais relevantes para um modelo comunicativo são: contextos existencial, situacional, textual e intertextual, que podem ser assim representados:

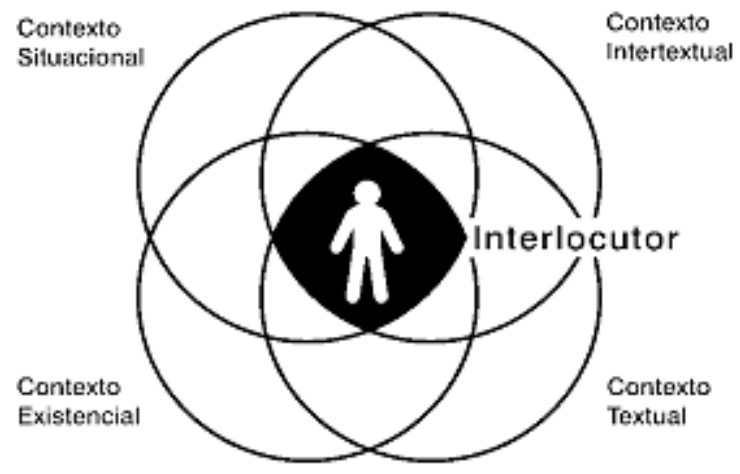

A noção de interlocutor se opõe às de "emissor e receptor", dissolvendo a estrutura linear e instaurando a idéia de que cada pessoa participa por inteiro do circuito produtivo que caracteriza a prática comunicativa. No modelo, os interlocutores são localizados nos nós da rede, significando que cada interlocutor é, simultaneamente, agente e espaço de negociação dos sentidos.

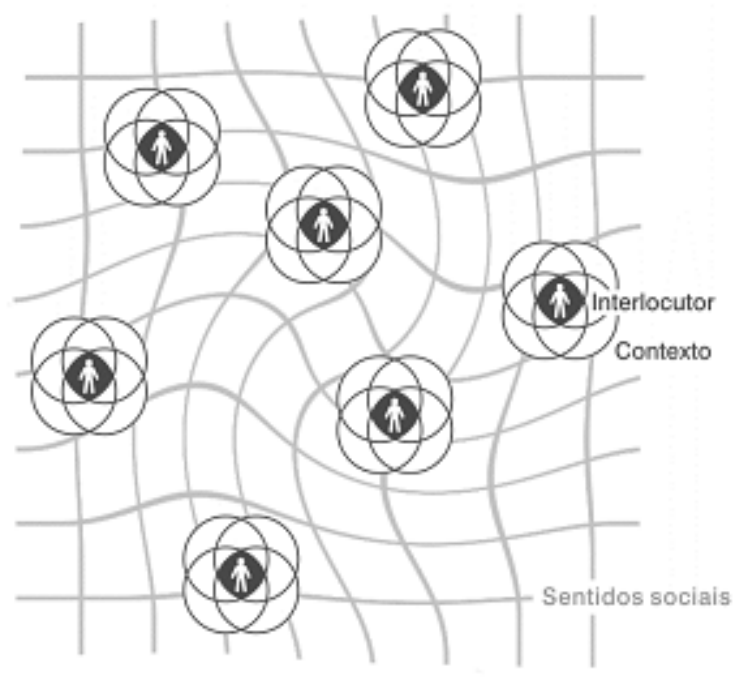




\section{Posições discursivas}

Neste modelo, Centro e Periferia são posições móveis e negociáveis. Optei por representá-las por uma espiral, que traz a idéia de movimento, fundamental para compreender a proposta.

A espiral concilia a idéia de rede e o descentramento e multilinearidade que lhe são inerentes, com a bipolaridade e linearidade da idéia de Centro e Periferia. O conceito chave é "negociação": num modelo que representa o circuito produtivo da comunicação, "negociação" é um conceito estratégico. Toda enunciação é um produto negociado e esta concepção permite evitar oposições simplistas e bipolares entre posições de poder discursivo.

A espiral também tenta solucionar a questão de como representar a desigualdade dos interlocutores quanto às condições de produção, circulação e consumo: justamente por meio da posição discursiva, mais ou menos distante do Centro ou da Periferia. O tema da desigualdade está presente em todo o modelo, que pode ser entendido como uma proposta de seu enfrentamento e superação. Ela está diretamente relacionada com cada etapa do circuito produtivo. Nas condições de produção, aparece de forma mais evidente, implicada na propriedade dos meios, no lugar de interlocução, na condição econômica (contexto existencial), no lugar que o interlocutor ocupa na topografia social e institucional (contexto situacional) etc. Mas, é na circulação, esquecida pelos demais modelos e tão desprezada pelo planejamento da comunicação nas políticas públicas, que se produz mais fortemente a exclusão social. Ou seja, na desigualdade das condições de se fazer circular os sentidos sociais. Quem consegue fazer circular os seus sentidos? Quem consegue ser ouvido? É ali que os sentidos dominantes ampliam sua hegemonia, ao silenciar os demais. O fenômeno da comunicação em rede (basicamente fluxos, circulação) acentuou a diferenciação, manifesta tanto na possibilidade de acesso, como no lugar que se ocupa nas redes. No mundo simbólico, nada assume existência antes de ser posto em circulação. É a circulação que confere existência aos produtos simbólicos, ao mesmo tempo em que a lança no espaço público. Eé justamente aí, na capacidade de fazer circular mensagens e sentidos privados, tornando-os públicos, que se localiza grande parte da assimetria no poder discursivo. Não é por acaso que as redes de comunicação são um dos principais alvos de quem procura acumular poder.

Há desigualdade de condições também no consumo, território onde finalmente se concretiza a hegemonia. O que se consome, de que forma, o uso possível das informações e do conhecimento, tudo isto é diferenciado de acordo com os contextos e lugares de interlocução. Localiza-se aí a questão do acesso a outras fontes de informação, tão cara ao movimento da democratização da comunicação e de setores específicos, como o da saúde coletiva. 
Quando a espiral é superposta à rede dos sentidos, espaço ocupado e operado pelos interlocutores, temos caracterizado o lugar de interlocução, posição que cada indivíduo ou comunidade discursiva ocupa no mercado simbólico. A representação corresponde, então, ao modelo completo.

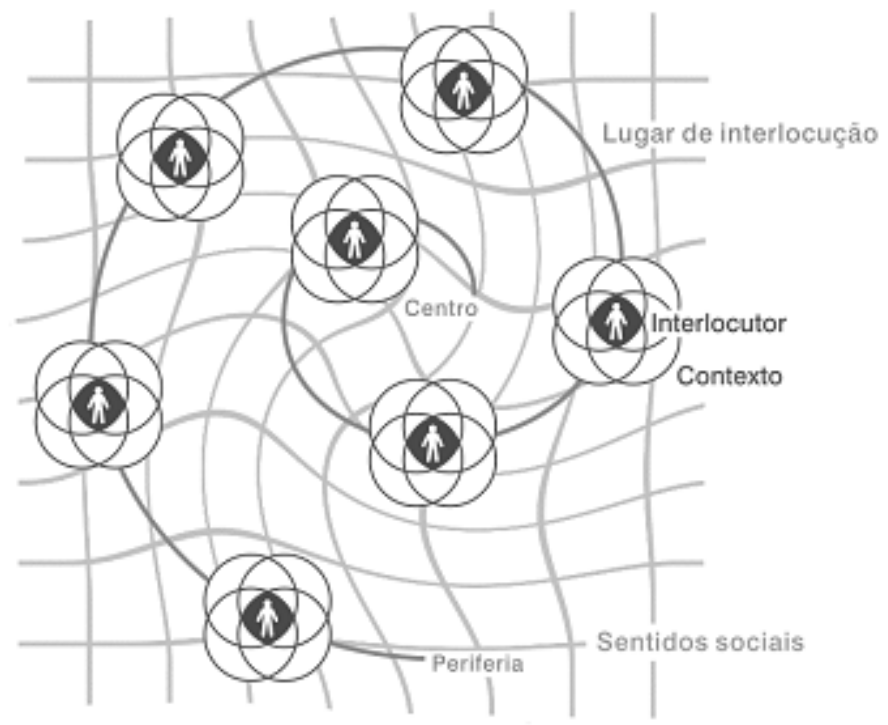

Este é um modelo reticular, multipolar, multidirecional, desenvolvido para compreensão da prática comunicativa no campo das políticas públicas. Ele faz sentido numa perspectiva analítica que considere as políticas públicas como espaço de confrontos sociais, que se dão pela via discursiva. Também requer que se considere, ao modo de Fairclough (2001), que os discursos trazem inerentes uma dimensão $e$ a possibilidade de transformação social. Neste sentido, o modelo, como instrumento de planejamento da comunicação, pretende também se opor às forças centrípetas de concentração de poder, na medida em que percebe os lugares de interlocução móveis e negociáveis. A compreensão dos fatores que permitem a mobilidade desses lugares pode ser propiciada por uma matriz de análise, cujo resumo exponho a seguir.

Matriz de análise dos fatores de mediação

Esta matriz tem como objetivo oferecer uma estrutura de análise das relações de poder na sociedade, no contexto das políticas públicas e na perspectiva discursiva, que remete para a negociação de lugares de interlocução mais favoráveis ao exercício do poder simbólico. Requer uma percepção do poder que considere a existência de posições discursivas matriciais, Centro e Periferia, que são móveis, relacionais, negociadas e por fatores de mediação, que são elementos simbólicos e materiais que promovem o fluxo dos interlocutores entre essas posições. É este espaço, onde se defrontam e se articulam as forças sociais, em busca do poder simbólico, que a Matriz busca sistematizar. 
Para compreendê-la, é necessário ter em vista que o estatuto do sujeito central ou periférico não é fixo: mesmo que se possa ser centro ou periferia, institucionalmente falando, discursivamente não se ocupa sempre a mesma posição. Pode-se afirmar que, de um modo geral: as estratégias desenvolvidas pelo centro tendem a ser no sentido de manutenção da ordem discursiva que lhes permita continuar ocupando essa posição de poder; $e$ as estratégias da periferia tendem a ser no sentido de permitir uma melhor posição na escala de poder discursivo, ou seja, um melhor lugar de interlocução.

Neste trabalho, entendo que mediação é a propriedade exercida pelo elemento que possibilita a conversão de uma realidade em outra. Os fatores de mediação, ao promoverem o fluxo dos interlocutores entre os diversos lugares de interlocução, favorecem e mesmo determinam o equilíbrio de forças. É, então, um conceito que encerra a idéia de movimento, mas também as de condições de produção, o que permite perceber que as mediações constróem os pólos da relação, não sendo destacáveis delas.

É impossível mapear todas as possibilidades mediadoras de uma prática discursiva. Elas compõem uma rede de sentidos, não apenas contextuais, mas também intertextuais, que mobilizam uma enorme diversidade de campos, instâncias e fatores. Como se sabe, o processo de semiose social é produto da articulação desses muitos âmbitos, cuja combinação em cada situação discursiva é particular e única. A paradoxal natureza desse processo, ao mesmo tempo ampla e restrita, aponta para a necessidade de uma matriz de análise que permita ao pesquisador ou ao planejador acercar-se de seu objeto de um modo mais preciso e delimitar um âmbito mais circunscrito de análise, sem perder de vista a interdiscursividade.

Foi este meu empreendimento: procurei estruturar uma matriz composta de níveis progressivamente mais restritos de mediações, assim classificados menos por sua importância na composição dos sentidos (a importância é definida pelos contextos) ou por seu grau de inerência aos sentidos (todos os níveis são constitutivos dos sentidos) e mais pela sua natureza e grau de especificação. Assim, fui do mais amplo - as fontes - ao mais restrito - os fatores de mediação entre as posições discursivas de poder, Centro e Periferia. A realidade empírica que se apresenta à utilização da matriz permite identificar um elenco de fatores, percebê-los como estratégias de produção de lugares de interlocução, relacioná-los e por fim classificá-los, de modo a facilitar seu uso como instrumento analítico e de planejamento.

\section{Componentes da Matriz}

Fontes - designa espaços simbólicos que organizam e produzem mediações a partir do acervo individual, social e cultural dos indivíduos e grupos sociais, os quais se apresentam como pré-construídos. Embora estejam sempre sendo atualizadas, em contextos específicos, pelas articulações com outros níveis, tendem a se apresentar como "cicatrizes dos sentidos", produzidas no campo da memória e do imaginário (discursos fundadores, sobretudo), que são acionadas em cada situação comunicativa $e$ em contextos específicos. Ex.: História, Cultura, Religião.

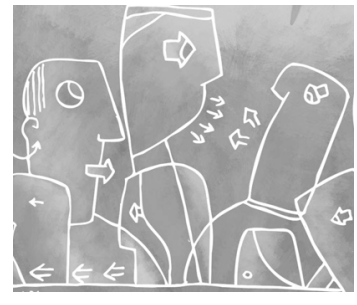


Campos - espaços sociodiscursivos de natureza abstrata, que podem ser mais ou menos estruturados. Ao primeiro tipo correspondem as instituições, como Estado, a Igreja, a Escola, o Mercado, as Forças Armadas, a Sociedade Civil etc. Ao segundo, as temáticas e práticas sociopolíticas, como a Saúde Coletiva, a Comunicação, o Ambientalismo (temáticas); o movimento da saúde indígena, o movimento da reforma sanitária, rituais mágico-religiosos (práticas sociopolíticas), entre outros.

Instâncias - espaços sociodiscursivos concretos, estruturados formalmente, como as organizações, mas também por princípios não formais de organização, como as famílias, por exemplo. As instâncias especificam os campos, mas não guardam uma relação de equivalência. Um campo pode compreender diversas instâncias e uma instância pode conferir materialidade a mais de um campo. Instâncias têm uma dimensão simbólica - território de articulação com outras instâncias e campos - que permeia uma outra dimensão, a material, representada por pessoas específicas, equipamentos, recursos, rotinas, tecnologia.

Comunidades discursivas - como antecipado, designa grupos de pessoas que produzem, fazem circular discursos, que neles se reconhecem $e$ são por eles reconhecidos.

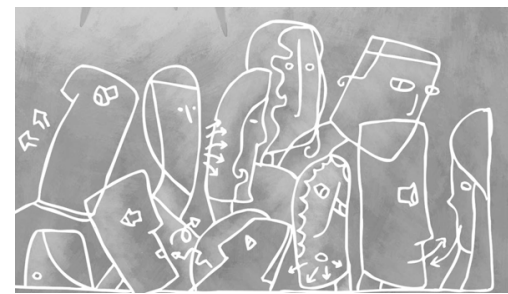

Estes grupos encarregados da produção e gestão textual possuem
uma hierarquia interna (instâncias de decisão e poder, um centro
e uma periferia) e uma organização de trabalho; desenvolvem
relações com outros que dividem o mesmo espaço discursivo, de
antagonismo ou cooperação; dispõem de mais ou menos recursos
financeiros e dependem de modo diferenciado das fontes
geradoras desses recursos; seus membros possuem uma história e
uma motivação para estar ali e desenvolver aquele trabalho. Estes
fatores afetam os discursos produzidos e as estratégias de
circulação. Não são, pois, meros porta-vozes de um discurso que
lhes transcende, mesmo que assim se julguem, sejam técnicos,
religiosos, ou militantes. (Araújo, 200o, p.161)

Na Matriz, as comunidades discursivas ocupam uma posição especificadora das instâncias. São o espaço onde se manifestam e podem ser observados os fatores de mediação.

Fatores - de natureza e amplitude diversas, os fatores emanam dos vários contextos analisados. Por outro lado, não possuem uma valoração em si mesmos, nem são em si mesmos estratégias de manutenção ou transformação da ordem dominante. Sua valoração está vinculada à noção de capital simbólico (Bourdieu, 1989). Ou seja, a posse em maior ou menor grau daquela propriedade confere capital simbólico ao interlocutor, modificando sua posição na escala de poder entre Centro e Periferia. É esse mecanismo que confere aos fatores de mediação valor como instrumento estratégico.

A partir de um elenco de fatores identificados num universo empírico estudado, emergiu uma tipologia de fatores. Em princípio, estes tipos têm relevância em situações de intervenção social e fazem sentido numa análise 
que se inscreva numa concepção de comunicação como um processo de produção, circulação e consumo dos sentidos sociais. Eis a matriz sistematizada:

Fontes

Campos

Instâncias

Comunidades discursivas

Fatores

1. Motivações e interesses

2. Relações

a. Relações pessoais, grupais e comunitárias

b. Relações institucionais e organizacionais

\section{Competências}

\section{Discursividades}

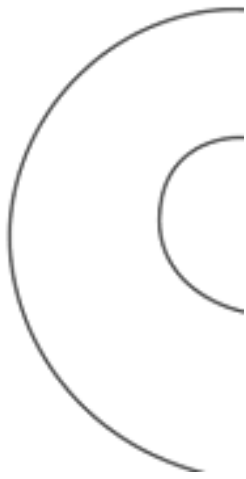
a. Discursos
b. Sistemas de nomeações
c. Paradigmas, teorias, modelos

\section{Dispositivos de comunicação}
a. Dispositivos de enunciação
b. Dispositivos de produção e circulação discursiva
c. Mediações tecnológicas

\section{Leis, normas e práticas convencionadas}

O princípio da interdiscursividade faz com que os fatores sejam mutuamente constitutivos. Por exemplo, os dispositivos de enunciação formam os discursos e são por eles formados; também incluem fatores de competência cultural e de relações de interlocução, que por sua vez são afetados pelos dispositivos; os dispositivos de produção e circulação discursiva são fortemente permeados pelas relações tecnológicas e pelas rotinas, cujo âmbito de significação é em parte estabelecido pelos dispositivos. Por outro lado, os espaços de organização coletiva, como fóruns e redes, tanto são fatores do tipo "relações institucionais", como podem ser incluídos nos dispositivos de produção e circulação discursiva, sejam como aparato de produção ou circulação ou mediação tecnológica.

\section{últimas palavras}

A noção de mercado simbólico se opõe à de "pensamento único" e assim como existe uma luta política para se contrapor ao pensamento único sobre a globalização, há a possibilidade de uma luta por um funcionamento do mercado simbólico mais eqüitativo. O modelo foi proposto no escopo de uma tese de doutorado, denominada "Mercado Simbólico: interlocução, luta, poder - Um modelo de comunicação para políticas públicas", defendida na Escola de Comunicação da Universidade Federal do Rio de Janeiro (ECO/ UFRJ), em novembro de 2002 (Araújo, 2002). As dimensões exigidas para este artigo permitiram apenas uma aproximação ao tema, que supõe maiores discussões quanto ao seu contexto teórico, metodológico e empírico. Quanto ao modelo, antes que possa assim ser intitulado 


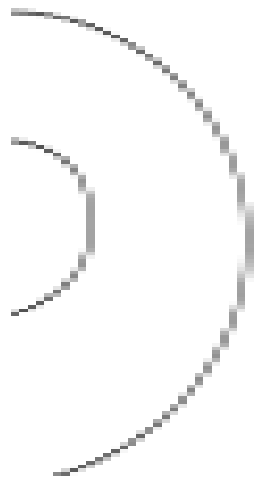

legitimamente, requer que não só seja submetido ao crivo teórico $e$ metodológico dos especialistas do campo da comunicação $e$ da intervenção social, mas também seja exposto à experimentação como modelo organizador do planejamento estratégico da comunicação aplicada às políticas públicas.

\section{Referências}

ARAÚJO, I. A reconversão do olhar: prática discursiva e produção do sentido na intervenção social. São Leopoldo: Unisinos, 2000.

ARAÚJO, I. Mercado Simbólico: interlocução, luta, poder - Um modelo de comunicação para políticas públicas. 2002. Tese (Doutorado) - Escola de Comunicação, Universidade Federal do Rio de Janeiro, Rio de Janeiro.

BAKHTIN, M. Marxismo e filosofia da linguagem. São Paulo: Hucitec, 1988.

BARBERO, J. M. De los medios a las mediaciones: comunicación, cultura y hegemonia. Barcelona: Gustavo Gilli, 1993.

BOURDIEU, P. O poder simbólico. Lisboa: Difel, 1989.

CANCLINI, N. G. Consumidores e cidadãos: conflitos multiculturais da globalização. Rio de Janeiro: Editora da UFRJ, 1995.

CERTEAU, M. A invenção do cotidiano: artes do fazer. Petrópolis: Vozes, 1994.

FAIRCLOUGH, N. Discurso e mudança social. Brasília: UnB, 2001.

MATTELART, A. Comunicação-Mundo: história das idéias e das estratégias. Petrópolis: Vozes, 1999.

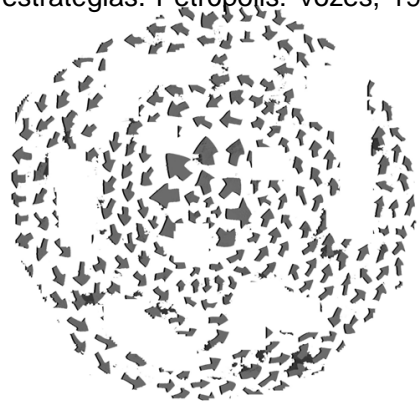

ARAújO, I. S. Mercado Simbólico: un modelo de comunicación para políticas públicas, Interface - Comunic., Saúde, Educ., v.8, n.14, p.165-77, set.2003-fev.2004.

El trabajo tiene como objetivo proponer un modelo para análisis y planificación estratégica de la comunicación en las políticas públicas, considerando que los modelos corrientes no sustentan adecuadamente la práctica comunicativa en los procesos de intervención social, frustrando las altas inversiones y expectativas que despiertan. El "Modelo del Mercado Simbólico", en red, descentrado y multipolar, es compuesto por una formulación teórica, una representación gráfica de los principales componentes y sus relaciones y de una matriz de análisis y planificación estratégica de las relaciones comunicativas. La representación gráfica contempla: la red de sentidos sociales, los interlocutores y sus contextos y "lugar de interlocución". La matriz incluye fuentes, campos, instancias, comunidades discursivas y una tipología de factores de mediación.

PALABRAS CLAVE: Comunicación y política publica; modelos de comunicación; planificación estratégica. 


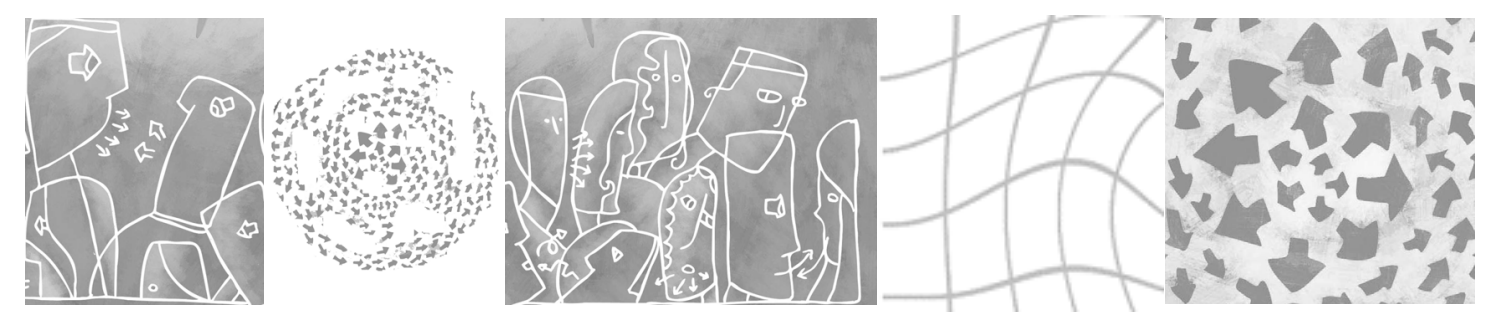

178 Interface - Comunic., Saúde, Educ., v.8, n.14, p.178, set.2003-fev.2004 